\title{
PENYULUHAN DAN PELAYANAN KESEHATAN TERNAK SAPI DI DESA KEMENUH GIANYAR
}

\author{
I.K.Berata ${ }^{1}$, I.M. Kardena ${ }^{2}$, I.B.O.Winaya ${ }^{3}$, N.N.W. Susari ${ }^{4}$, dan I.W. Sudira ${ }^{5}$
}

\begin{abstract}
ABSTRAK
Desa Kemenuh secara geografis sangat strategis sebagai kawasan agrowisata. Sektor peternakan, sebagai bagian dari program agrowisata, membutuhkan perhatian dan bimbingan berkelanjutan. Peternak sapi di desa Kemenuh masih rendah pengetahuan dan keterampilannya dalam memelihara ternak. Program ini bertujuan untuk menambah pengetahuan dan keterampilan petani. Dalam program penyuluhan disediakan waktu untuk diskusi antara tim penyuluh dan peternak. Setelah penyuluhan, dilanjutkan dengan pelayanan kesehatan berupa pengobatan ternak jika ada yang sakit, dan disertai dengan penjelasan tentang cara penanganan penyakit pada sapi. Sebanyak 52 ternak diperiksa dan diberi pengobatan gratis. Hasil pemeriksaan kesehatannya ditemukan sebanyak 10 ternak (19,23\%) anemia, 4 (7,69\%) kekurusan dan $1(1,92 \%)$ menunjukkan demam. Gejala anemia cukup tinggi, mungkin karena infestasi cacing atau kekurangan protein dalam pakannya. Dapat disimpulkan bahwa peternak masih membutuhkan bimbingan dalam upaya meningkatkan pengetahuan dan keterampilan mereka sehingga nilai jual ternak mereka lebih menguntungkan. Perlu dilakukan tindak lanjut untuk memeriksa darah dan feses ternak untuk mencari penyebab anemia dan kekurusan.
\end{abstract}

Kata kunci : Penyuluhan, pelayanan kesehatan, sapi, anemia, kekurusan

\begin{abstract}
Kemenuh village is geographically very strategic as an agrotourism area. The livestock sector, as part of an agrotourism program, requires continuous attention and guidance. Cattle farmers in Kemenuh village still be low his knowledge and skills in raising livestock. This program aims to increase the knowledge and skills of farmers. In counseling there is also time for discussion between extension team and farmers. After counseling, continued with health services and treatment of cattle if it be ill, and filled with explanations about ways of handling disease in cattle. A total of 52 cattles were examined and given free treatment. The results of its health examination were found as many as 10 cattles (19.23\%) anemia, 4 (7.69\%) emaciation and $1(1.92 \%)$ showed fever. Symptoms of anemia are quite high, possibly due to worm infestation or lack of protein in their feed. It can be concluded that cattle farmers still need guidance in an effort to increase their knowledge and skills so that the selling value of their cattle is more profitable. There is a need to check cattle's blood and feces to look for the causes of anemia and emaciation.
\end{abstract}

\footnotetext{
${ }^{1}$ Staf pengajar Fakultas Kedokteran Hewan Universitas Udayana, berata_iketut@unud.ac.id

${ }^{2}$ Staf pengajar Fakultas Kedokteran Hewan Universitas Udayana, imadekardena@unud.ac.id

${ }^{3}$ Staf pengajar Fakultas Kedokteran Hewan Universitas Udayana, okawinaya@unud.ac.id

${ }^{4}$ Staf pengajar Fakultas Kedokteran Hewan Universitas Udayana, nnwsusari@unud.ac.id

${ }^{5}$ Staf pengajar Fakultas Kedokteran Hewan Universitas Udayana, wayan.sudira@unud.ac.id
} 
Key words : Counseling, health services, cattle, anemia, emaciation.

\section{PENDAhUluAN}

Desa Kemenuh terletak di Kecamatan Sukawati, Kabupaten Gianyar, Bali. Desa Kemenuh dibagi menjadi 11 (sebelas) banjar dinas dan 6 desa adat. Lokasi desa Kemenuh sangat strategis karena berbatasan dengan desadesa objek wisata yaitu desa Peliatan pada sisi utara, berbatasan dengan desa Batuan dan desa Sukawati pada sisi selatan, desa Mas di sisi barat. Pada sisi sebelah timur berbatasan dengan sungai Petanu. Desa ini memiliki luas area sebesar 734 Ha dengan sekitar 4.000 penduduk. Dari 734 Ha area desa tersebut terbagi atas beberapa kawasan yaitu 75 Ha yang merupakan kawasan pemukiman, 205 Ha merupakan kawasan persawahan, $235 \mathrm{Ha}$ kawasan perkebunan, 218 Ha kawasan tempat ibadah dan lainnya dipergunakan untuk fasilitas umum, jalan. Lahan persawahan dan perkebunan sebagian besar digunakan untuk menanam padi dan palawija, dan peternakan terutama sapi.

Di desa Kemenuh terdapat dua kelompok ternak sapi yang tergabung dalam kelompok SIMANTRI, memiliki potensi untuk lebih dikembangkan. Sebagian peternak sapi di desa Kemenuh bersifat perseorangan, karena dianggap sebagai kerja sampingan. Pada saat terpuruknya kepariwisataan seperti akibat meletusnya Gunung Agung yang lalu, maka beternak sapi kembali sebagai pekerjaan yang diprioritaskan. Sapi bali yang bersifat adaptif terhadap lingkungan dengan ketersediaan pakan terbatas (Martojo, 2002), sangat cocok untuk daerah dengan lahan terbatas, seperti desa Kemenuh.

Peternak-peternak sapi yang baru terutama yang beralih dari pekerja pariwisata, umumnya sangat awam tentang cara-cara dan kendala-kendala yang mungkin terjadi dalam beternak sapi. Di desa Kemenuh terdapat sekitar 200 peternak sapi dengan rata-rata memiliki 2-3 ekor, sehingga secara keseluruhan terdapat 600 ekor sapi. Jumlah tersebut belum termasuk peternak baru yang beralih dari kerja bidang pariwisata akibat berbagai sebab. Dengan adanya peternak-peternak yang baru, maka perlu dilakukan penyuluhan serta peningkatan keterampilan cara-cara penanganan penyakit pada ternak sapi.

\section{METODE PELAKSANAAN}

Sesuai dengan masalah-masalah yang telah diinventarisasi sebelumnya, maka langkah-langkah pemecahan masalah dibagi atas 2 langkah umum yaitu :

1. Penyuluhan yaitu upaya peningkatan pengetahuan, ketarmpilan dan perilaku peternak agar beternak lebih efisien dan menguntungkan. Sesuai definisi dari penyuluhan adalah pemberian informasi baik berupa pengetahuan, keterampilan dan sikap sehingga secara keseluruhan terjadi perubahan sikap perilaku (Rismajayanti, 2012)

2. Pelayanan kesehatan ternak sapi, yaitu upaya memberikan bantuan mengatasi berbagai penyakit pada ternak sapi sekaligus memberikan contoh kepada peternak dalam melakukan penanganan penyakit sapi.

\section{HASIL DAN PEMBAHASAN}

Sebagai sasaran utama dalam kegiatan pengabdian kepada masyarakat ini adalah peternak tradisional. Walaupun demikian sebagai acuan sistem peternakan yang digunakan adalah kelompok Simantri "SATWA LESTARI" yang telah menjadi contoh untuk kelompok Simantri yang lainnya. Hasil dari pengabdian berupa permasalahan serta penanganan dari permasalahan yang dijumpai terangkum dalam Tabel 1 . 
Tabel 1. Hasil pengabdian kepada masyarakat peternak di desa Kemenuh-Gianyar

\begin{tabular}{|c|c|c|c|}
\hline No & Nama Peternak & Masalah & Penanganan \\
\hline 1 & Md Rawa & Sapi 1 -sehat & Disuntik vit B pleks \\
\hline 2 & Mudra & $\begin{array}{l}\text { Sapi } 2=\text { Sehat } \\
\text { Sapi } 1=\text { sehat }\end{array}$ & $\begin{array}{l}\text { Disuntik Vit B Plex } \\
\text { Disuntik vit B pleks }\end{array}$ \\
\hline 3 & Nyoman Kacir & $\begin{array}{l}\text { Sapi } 2=\text { sehat } \\
\text { Sapi } 1=\text { kurus }\end{array}$ & $\begin{array}{l}\text { Disuntik Vit B Plex } \\
\text { Beri obat cacing }\end{array}$ \\
\hline 4 & Sudiarsa & $\begin{array}{l}\text { Sapi } 2=\text { sehat } \\
\text { Sapi } 1\end{array}$ & $\begin{array}{l}\text { Disuntik Vit Bplex } \\
\text { Beri obat cacing }\end{array}$ \\
\hline $\begin{array}{l}5 \\
6 \\
7 \\
8\end{array}$ & $\begin{array}{l}\text { Katon } \\
\text { Kania } \\
\text { Pak Wija } \\
\text { Pak Grenyek }\end{array}$ & $\begin{array}{l}\text { Sapi } 2 \\
\text { sehat } \\
\text { sehat } \\
\text { sehat } \\
\text { Sapi } 1\end{array}$ & $\begin{array}{l}\text { Disuntik Vit Bplex } \\
\text { Disuntik Vit B Plex } \\
\text { Disuntik Vit B Plex } \\
\text { Disuntik Vit B Plex } \\
\text { Disuntik Vit B Plex }\end{array}$ \\
\hline 9 & Nase & $\begin{array}{l}\text { Sapi } 2 \\
\text { Anemia }\end{array}$ & $\begin{array}{l}\text { Diberi obat cacing } \\
\text { Disuntik Vit B Plex }\end{array}$ \\
\hline 10 & Maji & Kurus & $\begin{array}{l}\text { Diberi obat cacing } \\
\text { Disuntik Vit B Plex }\end{array}$ \\
\hline 11 & Darma & Sapi 1 & $\begin{array}{l}\text { Diberi obat cacing } \\
\text { Disuntik Vit B Plex }\end{array}$ \\
\hline $\begin{array}{l}12 \\
13 \\
14\end{array}$ & $\begin{array}{l}\text { Nyoman Toko } \\
\text { Abra } \\
\text { Kasub }\end{array}$ & $\begin{array}{l}\text { Sapi } 2 \\
\text { sehat } \\
\text { sehat } \\
\text { Demam }\end{array}$ & $\begin{array}{l}\text { Diberi obat cacing } \\
\text { Disuntik Vit B Plex } \\
\text { Disuntik Vit B Plex } \\
\text { Disuntik Vit B Plex }\end{array}$ \\
\hline $\begin{array}{l}15 \\
16 \\
17\end{array}$ & $\begin{array}{l}\text { Wayan Rata } \\
\text { Genting } \\
\text { Gusti Sweca }\end{array}$ & $\begin{array}{l}\text { sehat } \\
\text { sehat } \\
\text { Sapi } 1\end{array}$ & $\begin{array}{l}\text { Antibiotika (Kaloxi) } \\
\text { Disuntik Vit B Plex } \\
\text { Disuntik Vit B Plex } \\
\text { Disuntik Vit B Plex }\end{array}$ \\
\hline 18 & Selamat & $\begin{array}{l}\text { Sapi } 2 \\
\text { kurus }\end{array}$ & $\begin{array}{l}\text { Diberi obat cacing } \\
\text { Disuntik Vit B Plex }\end{array}$ \\
\hline 19 & Made Kliwes & Sapi $1=$ sehat & $\begin{array}{l}\text { Diberi obat cacing } \\
\text { Disuntik Vit B Plex }\end{array}$ \\
\hline & & Sapi 2 -sehat & Disuntik Vit B Plex \\
\hline & & Sapi $3=$ kurus & Diberi obat cacing \\
\hline & & Sapi $4=$ anemis & Disuntik Vit B Plex \\
\hline & & Sapi $5=$ anemis & Disuntik Vit B Plex \\
\hline & & Sapi 6 - anemis & Disuntik Vit B Plex \\
\hline
\end{tabular}


I Wayan Raka Arianata

Made Warta

Nyoman Wari

Made Wasdana

Made Agus Susila

Wayan Suasta

Made Suada

Made Rigun

Made Brathanata

Made Jaya

Wayan Baglur

Made Sukawati

I Ketut Nik

I Ketut Selender

Wayan Netra

Made Cetug

I Ketut Wiranata

I Ketut Jaga

I Wayan Dana
Sehat

Anemia

Kurus

Sehat

Sapi $1=$ sehat

Sapi $2=$ sehat

Sehat

Anemia

Sapi $1=$ anemia

Sapi 2 = anemia

Sehat

sehat

Kurus

Sehat

Sehat

Anemia

Anemia

Anemia

Sehat

Sehat

Kurus
Disuntik Vit B Plex

Disuntik Vit B Plex dan

obat cacing

Disuntik Vit B Plex dan

obat cacing

Disuntik Vit B Plex dan

obat cacing

Disuntik Vit B Plex

Disuntik Vit B Plex

Disuntik Vit B Plex

Disuntik Vit B Plex dan obat cacing

Disuntik Vit B Plex dan obat cacing

Disuntik Vit B Plex dan obat cacing

Disuntik Vit B Plex

Disuntik Vit B Plex

Disuntik Vit B Plex dan obat cacing

Disuntik Vit B Plex

Disuntik Vit B Plex

Disuntik Vit B Plex dan obat cacing

Disuntik Vit B Plex dan obat cacing

Disuntik Vit B Plex dan obat cacing

Disuntik Vit B Plex

Disuntik Vit B Plex

Disuntik Vit B Plex dan obat cacing

Jumlah sapi 52 ekor

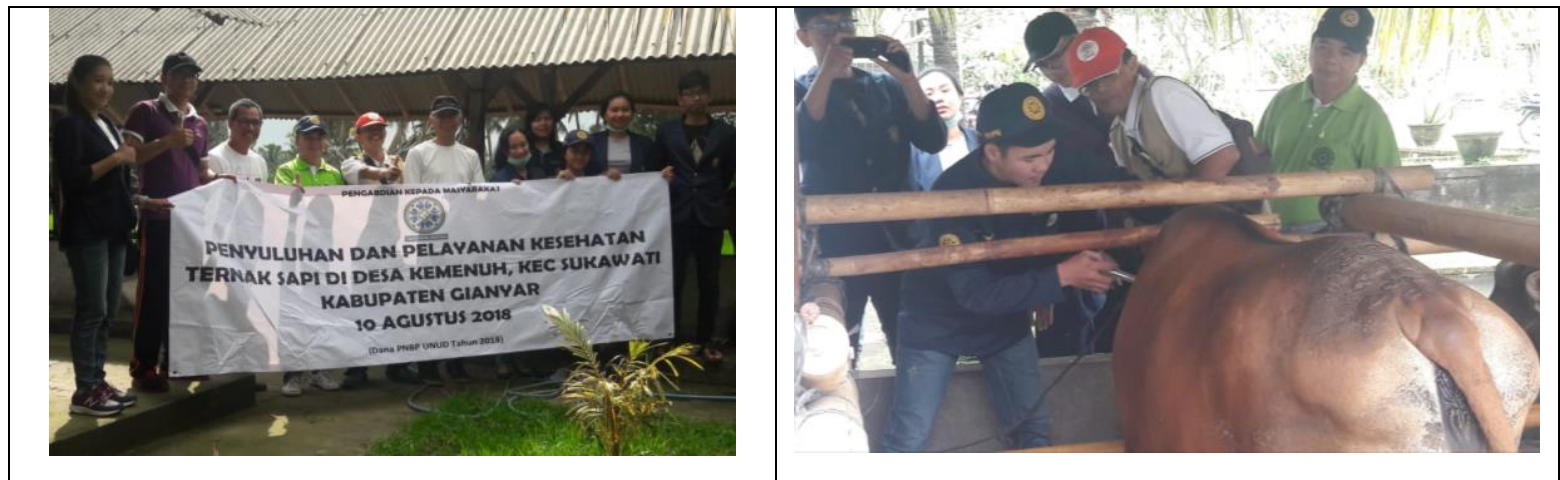

Gambar 1. Pelaksanaan kegiatan pengabdian di lapangan. Kanan: sesaat sebelum dilakukan penyuluhan. Kiri: saat dilakukan pengobatan pada ternak sapi.

Dari hasil penyuluhan, tampak antusiasme peternak menyimak materi penyuluhan yang diberikan. Indikasi dari antusiasme tersebut adalah munculnya pertanyaan-pertanyaan dalam diskusi yang berlanjut pada

\section{0 | BULETIN UDAYANA MENGABDI}


pemeriksaan kesehatan ternak sapinya. Menurut Rismajayanti (2012) menyatakan bahwa keberhasilan suatu penyuluhan ditandai dengan tingkat respon peserta. Pertanyaan-pertanyaan meliputi hal-hal pemilihan bibit, pemberian pakan, penanganan limbah, pencegahan serta pengobatan dan pemasaran ternak sapi.

Dalam pelaksanaan pelayanan kesehatan ternak sapinya juga terjadi diskusi interaktif tentang penyebab sakitnya ternak. Penyakit pada sapi dapat disebabkan oleh virus, bakteri, parasit (endoparasit dan ektoparasit), jamur dan keracunan. Dari 52 ekor sapi yang diperiksa ditemukan 10 ekor $(19,23 \%)$ mengalami anemia, 4 ekor mengalami kekurusan $(7,69 \%)$ dan 1 ekor mengalami demam (1.92\%). Kejadian anemia dapat disebabkan oleh berbagai sebab diantaranya asupan pakan (protein) yang kurang, gangguan penyerapan nutrisi di usus, infestasi parasit usus dan bisa juga akibat keracunan.

Defisiensi nutrisi sering terjadi akibat hijauan pakan yang kurang, karena sapi bali dikenal sangat adaftif terhadap lingkungan. Hal ini terlihat dari ketahanan sapi bali yang dipelihara pada tempat pembuangan sampah (Payne, et al, 1997). Endoparasit sering ditengarai sebagai penyebab anemia pada sapi. Cacing dalam usus mengisap nutrisi maupun darah dalam usus sapi, sehingga sapi sendiri mengalami defisiensi nutrisi yang berlanjut menjadi anemia (Taylor, et al, 2007). Keracunan logam berat pada sapi yang dipelihara di tempat pembuangan sampah perkotaan, juga dapat menyebabkan anemia (Berata, et al, 2016).

Adanya demam pada satu ekor sapi $(1,92 \%)$ saat pengabdian masyarakat, menunjukkan kecilnya angka sakit (mortalitas) akibat penyakit infeksius. Penyakit infeksius umumnya menimbulkan respon radang dan tampaknya. Penyakit infeksius pada sapi dapat disebabkan oleh virus, bakteri, jamur dan parasit (PKSB Unud, 2012).

\section{KESIMPULAN DAN SARAN}

Secara umum kebanyakan peternak sudah berpengalaman beternak sapi, sehingga pengetahuan dan keterampilan beternak sudah cukup memadai. Walaupun demikian, ada beberapa ternak sapinya yang mengalami anemia $=19,23 \%$, kekurusan $=7,69 \%$ dan demam $1,92 \%$.

Perlu pemantauan secara terkoordinasi terhadap peternak sapi di Desa Kemenuh, dari instansi terkait secara berkesinambungan.

\section{UCAPAN TERIMAKASIH}

Terimakasih kepada Rektor Universitas Udayana melalui Ketua Lembaga Penelitian dan Pengabdian kepada Masyarakat, atas dana PNBP tahun anggaran 2018 untuk program pengabdian skim Udayana Mengabdi ini.

\section{DAFTAR PUSTAKA}

Berata, I K., Susari N.N.W., Kardena, I M., Ariana, I N.T. (2016). Cemaran Timah Hitam dalam Darah Sapi Bali yang Dipelihara di Tempat Pembuangan Akhir Kota Denpasar. J.Vet 17 (4): 641-6.

Martojo, H. (2002). A Simple selection program for smalholder Bali cattle farmers. In: Proceeding of an ACIAR Workshop on "Strategies to Improve Bali Cattle in Eastern Indonesia", Denpasar Bali, Indonesia.

Payne, W.J.A. and J.Hodges. (1997).Tropical Cattle :Origin, Breeds and Breeding Policies. Blackwell Science.

Pusat Kajian Sapi Bali (PKSB) Unud. (2012). Sapi Bali Sumberdaya Genetik Asli Indonesia. Udayana University Press.

Rismajayanti, (2012). Sejarah dan Pengertian Penyuluhan. Wikipedia. Akses tgl 14 Februari 2018. 
PENYULUHAN DAN PELAYANAN KESEHATAN TERNAK SAPI DI DESA KEMENUH GIANYAR

Taylor, MA., Coop, RL., Wall, RL. (2007). Veterinary Parasitology. $3^{\text {rd }}$.Ed. Blackwell Publishing. 